\title{
Targeted therapies for patients with advanced NSCLC harboring wild-type EGFR: what's new and what's enough
}

\author{
Fei Zhou and Cai-Cun Zhou*
}

\begin{abstract}
Historically, non-small cell lung cancer (NSCLC) is divided into squamous and nonsquamous subtypes based on histologic features. With a growing number of oncogenic drivers being identified in squamous and nonsquamous NSCLC, this malignancy has been recently divided into several distinct subtypes according to the specific molecular alterations. This new paradigm has substantially highlighted the treatment of advanced NSCLC, shifting it from standard chemotherapy according to specific histologic subtypes to targeted therapy according to specific oncogenic drivers. The application of epidermal growth factor receptor (EGFR)-tyrosine kinase inhibitors (TKIs) in NSCLC patients harboring activating EGFR mutations has been a representative model of precise medicine in the treatment of NSCLC. As the role of EGFR-TKIs in routine management of patients with advanced NSCLC has been well established, this review provides an overview of alternative targeted therapy in the treatment of NSCLC, including EGFR-TKIs for patients with wild-type EGFR NSCLC, as well as other targeted agents either clinical available or in early- to late-stage development.

Keywords: Epidermal growth factor receptor (EGRF), EGFR mutation, Anaplastic lymphoma kinase (ALK),

ALK rearrangement, Molecular targeted therapy, Non-small cell lung cancer
\end{abstract}

\section{Background}

Lung cancer remains the leading cause of cancer-related deaths worldwide, of which non-small cell lung cancer (NSCLC) is the most frequent type [1-3]. The majority of patients with NSCLC have locally advanced or metastatic disease at the time of diagnosis. For a long period, chemotherapy have served as the only backbone of therapeutic strategy for patients with this malignancy, of whom the prognosis is very poor, with a median survival time of only $8-10$ months and 5-year survival rate less than $20 \%$ $[4,5]$.

Over the past decade, a great effort has been made regarding the understanding of cancer biology and molecular genetics of NSCLC, and we have witnessed tremendous advances in the management of patients with advanced NSCLC. Based on the presence of specific

*Correspondence: caicunzhoudr@163.com

Department of Medical Oncology, Shanghai Pulmonary Hospital,

Tongji University School of Medicine, Shanghai 200433, P. R. China molecular alterations (oncogenic drivers), NSCLC has been recently divided into several distinct subtypes.

Among the emerging driver oncogenes, epidermal growth factor receptor (EGFR) mutation is one of the most important molecular aberrations in patients with NSCLC. Numerous clinical trials have documented the striking efficacy of EGFR-tyrosine kinase inhibitors (EGFR-TKIs), namely erlotinib, gefitinib, and afatinib, in advanced NSCLC patients with activating EGFR mutations [6-13]. As compared with standard chemotherapeutic regimen, EGFR-TKIs significantly improve objective response rate (ORR), progression-free survival (PFS), and quality of life (QoL) and show mild toxicity. In light of the remarkable progress highlighted by the use of EGFR-TKIs, the treatment of NSCLC has stepped into an era of targeted therapy and precise medicine.

In current clinical practice, it is standard to analyze EGFR mutation status in patients with advanced NSCLC when diagnosed. For NSCLC patients harboring activating EGFR mutations, EGFR-TKIs are recommended in first-line treatment paradigm. Notably, absence of 
activating EGFR mutation does not imply that chemotherapy remains the only option for patients with wildtype EGFR NSCLC. It is intriguing that even in patients with wild-type EGFR NSCLC, a considerable proportion of patients may still achieve clinical benefit from EGFR-TKI treatment. Moreover, recent advances in the development of molecular classification of NSCLC have revealed that the majority of driver oncogenes in NSCLC are mutually exclusive of other genetic abnormalities. Therefore, further molecular analysis of wild-type EGFR NSCLC might identify additional driver oncogenes (i.e., anaplastic lymphoma kinase $[A L K]$, c-ros oncogene 1 [ROS1] or rearranged during transfection [RET] rearrangement, proto-oncogene protein c-met $[M E T]$ amplification, human epidermal growth factor receptor 2 [HER2] mutation or amplification, $\mathrm{v}$-Raf murine sarcoma viral oncogene homolog B1 [BRAF] mutation, fibroblast growth factor receptor 1 [FGFR1] amplifications, and discoidin domain receptor-2 [DDR2] mutations) and provide alternative targeted therapies.

As the role of EGFR-TKIs in routine management of advanced NSCLC patients harboring activating EGFR mutations have been well established, this review focuses on alternative targeted therapy in the treatment of NSCLC, including EGFR-TKIs for patients with wildtype EGFR NSCLC. Other targeted agents either clinical available or in early- to late-stage clinical trials will also be discussed.

\section{EGFR-TKIs in patients with wild-type EGFR NSCLC}

Clear evidence has demonstrated that EGFR-TKIs should not be used in first-line treatment paradigm in patients with wild-type EGFR NSCLC [14]. In the landmark BR.21 study [15], erlotinib significantly prolonged both PFS (2.2 versus 1.8 months; hazard ratio [HR], 0.61; 95\% confidence interval $[\mathrm{CI}], 0.51-0.74 ; P<0.001)$ and overall survival (OS, 6.7 versus 4.7 months; $H R, 0.70$; $95 \%$ CI, $0.58-0.85 ; P<0.001$ ) compared with placebo in previously treated patients with advanced NSCLC. The
INTEREST [16] and TITAN [17] studies further demonstrated that EGFR-TKIs are not inferior standard second-line chemotherapy (docetaxel or pemetrexed) for unselected NSCLC patients. What is the role of EGFRTKIs as second-line therapy for patients with wild-type EGFR NSCLC?

The TAILOR study addressed this issue. In TAILOR study [18], patients assigned to the chemotherapy arm (docetaxel) experienced a statistically significant improvement in PFS (2.9 versus 2.4 months; HR, 0.71; 95\% CI, 0.53-0.92; $P=0.02)$ and OS (8.2 versus 5.4 months; HR, 0.73; 95\% CI, 0.53-1.00; $P=0.05$ ) compared with erlotinib in second-line therapy for patients with advanced wild-type EGFR NSCLC. The DELTA study and CTONG0806 studies consistently supported the conclusions of the TAILOR study. In DELTA study [19], erlotinib was significantly inferior to docetaxel in terms of PFS (1.3 versus 2.9 months; HR, 1.45; 95\% CI, $1.09-1.94 ; P=0.01)$ and ORR (5.6\% versus $20.0 \%$, $P<0.01)$ in patients with wild-type EGFR NSCLC. In CTONG0806 study [20], patients assigned to the chemotherapy arm (pemetrexed) experienced a statistically significant improvement in PFS (4.8 versus 1.6 months; HR, $0.54 ; 95 \% \mathrm{CI}, 0.40-0.75 ; P<0.001)$ and a trend toward improvement in OS (12.4 versus 9.6 months; HR, 0.72, 95\% CI 0.49-1.04; $P=0.077$ ) compared with gefitinib in second-line therapy for patients with advanced nonsquamous NSCLC harboring wild-type EGFR mutations (Table 1). Moreover, a recent meta-analysis including 1,605 patients with wild-type EGFR NSCLC in 11 trials demonstrated that chemotherapy showed a superiority in terms of PFS (HR, 1.84; 95\% CI, 1.35-2.52) and ORR (16.8 versus $7.2 \%$; relative risk, 1.11 ; $95 \% \mathrm{CI}, 1.02-1.21$ ) compared with EGFR-TKIs [21].

Do these results mean that EGFR-TKIs should be absolutely banned in patients with wild-type EGFR NSCLC? Not necessary. In clinical practice, a considerable proportion of patients with wild-type EGFR NSCLC may achieve clinical benefit from EGFR-TKIs. Therefore, to discover

Table 1 EGFR-TKIs versus chemotherapy as second-line treatment for advanced NSCLC patients harboring wild-type EGFR mutations

\begin{tabular}{|c|c|c|c|c|c|c|c|}
\hline Trial & Detection technique & Treatment & PFS (months) & HR for PFS $(95 \% \mathrm{Cl})$ & OS (months) & HR for OS $(95 \% \mathrm{Cl})$ & Reference \\
\hline \multirow[t]{2}{*}{ TAILOR } & Sequencing & Erlotinib & 2.4 & $0.71(0.53-0.95)$ & 5.4 & $0.73(0.53-1.00)$ & {$[18]$} \\
\hline & & Docetaxel & 2.9 & & 8.2 & & \\
\hline \multirow[t]{2}{*}{ DELTA } & PCR-based methods & Erlotinib & 1.3 & $1.45(1.09-1.94)$ & 9.0 & $0.98(0.69-1.39)$ & [19] \\
\hline & & Docetaxel & 2.9 & & 10.1 & & \\
\hline \multirow[t]{2}{*}{ CTONG0806 } & DNA sequencing & Gefitinib & 1.7 & $0.53(0.38-0.75)$ & 9.6 & $0.72(0.49-1.04)$ & {$[20]$} \\
\hline & ARMS & Pemetrexed & 5.6 & & 12.4 & & \\
\hline
\end{tabular}

EGFR epidermal growth factor receptor, TKIs tyrosine kinase inhibitors, NSCLC non-small cell lung cancer, $P C R$ polymerase chain reaction, ARMS Scorpion amplification refractory mutation system, PFS progression-free survival, $\mathrm{HR}$ hazard ratio, $\mathrm{Cl}$ confidence interval, $\mathrm{OS}$ overall survival. 
the potential mechanism or to identify applicable population who may benefit from EGFR-TKIs is of clinical value, especially for patients who do not have specific molecular alterations. The clinically validated, serum-based protein test called VeriStrat (Biodesix, Broomfield, CO, USA) may be a promising strategy to achieve this goal. The PROSE study was to prospectively evaluate the predictive utility of VerStrat on the survival of NSCLC patients treated with second-line erlotinib or chemotherapy [22]. Patients were classified into Good and Poor groups based on VerStrat. In VerStrat Good group of NSCLC patients with wild-type or unknown status $E G F R$, the OS was not different between the patients treated with chemotherapy and those treated with erlotinib (10.9 versus 11.0 months; HR, 1.06; 95\% CI, 0.77-1.46; $P=0.714$ ), suggesting that EGFR-TKIs could be a rational choice for this subpopulation in second-line setting. Recently, $\mathrm{Li}$ et al. [23] reported that patients with higher microRNA-200c expression achieved longer PFS (5.0 versus 1.2 months; HR, 0.38 ; $95 \% \mathrm{CI}, 0.21-0.70, P=0.002)$ and $\mathrm{OS}$ (9.6 versus 5.0 months; HR, 0.54 ; $95 \% \mathrm{CI}, 0.30-0.96, P=0.035$ ) than those with lower microRNA-200c expression in patients with wild-type EGFR NSCLC. Ren et al. [24] more recently found that patients with epithelial phenotype responded better to EGFR-TKIs than those with epithelial-to-mesenchymal or mesenchymal phenotype in patients with wild-type EGFR NSCLC in terms of PFS (4.4 versus 1.9 versus 1.0 months, $P<0.001)$ and $O S(11.5$ versus 8.9 versus 4.9 months, $P<0.001$ ). In a recent study by Toffalorio et al. [25], among patients with wild-type EGFR NSCLC, 13 patients with high polysomy of chromosome 7 received erlotinib, in which the disease control rate was as high as $76.9 \%$ (1 patient with complete response, 4 patients with partial response, and 5 patients with stable disease); the mean time-to-progression in this subpopulation was 9 months, suggesting a potential role of high polysomy of chromosome 7 as a useful biomarker to identify patients harboring wild-type EGFR mutations who may benefit from EGFR-TKIs. The survival in aforementioned subpopulations, namely wild-type EGFR NSCLC patients with higher microRNA-200c expression, epithelial phenotype, or high polysomy of chromosome 7 is promising, and it deserves further investigation in these subpopulations.

\section{EGFR mutation detection methods}

Interestingly, in the CTONG0806 study [20], compared with Scorpion amplification refractory mutation system (ARMS) method, false negative rate of DNA sequencing was $29.6 \%(32 / 108)$. The ORR of patients treated with gefitinib in ARMS mutation-positive group was higher than that in ARMS mutation-negative group (38.5 versus $10.5 \%, P=0.09$ ). Consequently, the results of
CTONG0806 study raised a controversial issue in clinical practice: which method should be used to detect EGFR mutations?

Among a variety of methods used for EGFR mutation genotyping, Sanger sequencing has been the most widely used method, which is often considered the "gold standard" for EGFR mutation testing [26]. However, Sanger sequencing is recommended when the percentage of tumor cell contents in the sample is at least 50\% [27]. Hence, Sanger sequencing may offer limited sensitivity, and false negative results can occur more frequently in small biopsy samples without sufficient tumor cell contents or high-quality DNA. Immunohistochemistry (IHC) assay using commercially available mutation-specific rabbit monoclonal antibodies directly against two major forms of EGFR mutations, namely deletions in exon 19 and L858R point mutation, demonstrated a high concordance with Sanger sequencing, with an excellent sensitivity of $92 \%$ and specificity of $99 \%$ [28]. Although mutation-specific IHC has been demonstrated to be a rapid, sensitive, and cost-effective method for detecting the two predefined EGFR mutations [29-32], even in small bronchial biopsy samples [33], other uncommon EGFR mutations, including T790M mutations, cannot be detected by the mutation-specific antibodies; it is currently lack of sufficient data to make an evidence-based recommendation for the use of IHC assay for EGFR mutation detection $[27,34]$. A number of polymerase chain reaction (PCR)-based assays have also been employed for EGFR mutation testing, including ARMS (DxS, Manchester, UK) [35], cationic conjugated polymer (CCP)-based fluorescence resonance energy transfer (FRET) [36], peptide nucleic acid-locked nucleic acid (PNA-LNA) PCR clamp (Stratagene, La Jolla, CA, USA) [37], denaturing high-performance liquid chromatography (HPLC) (Transgenomic, Omaha, NE, USA) [38], MassARRAY System (Sequenom Inc., San Diego, CA, USA) [39], SNaPshot assay (Applied Biosystems, Life Technologies, Foster, CA, USA) [40, 41], and TaqMan Mutation Detection Assay (Applied Biosystems, Life Technologies, Foster, CA, USA) [42]. Compared with Sanger sequencing, the PCR-based assays are rapid and more sensitive and have ability to detect a mutant EGFR sequence in small biopsy specimens containing less that $10 \%$ mutated DNA, including cell block samples [43]. The main theoretical drawback of these PCR-based assays is their inability to detect some of the rare EGFR mutations which are detectable by direct sequencing [44].

As mentioned above, each method for EGFR mutation testing has its own strengths and limitations. In general, for samples with high tumor cell contents, the majority genotyping methods are suitable; however, for samples without sufficient tumor cell contents, more 
sensitive methods are preferable. Furthermore, the choice of method in clinical practice should be made based on the testing laboratory's expertise, detection instrument, and the detection purpose.

Coming back to our topic, which method should be used to confirm a "true" wild-type EGFR mutation? Notably, patients with a low abundance of EGFR mutations (ARMS positive but sequencing negative) achieved more clinical benefits from EGFR-TKIs than those with wild-type EGFR NSCLC (both ARMS and sequence negative) with respect to both PFS and OS [45]. Similar survival benefit trend was also observed in the CTONG0806 study [20]. Since patients with a low abundance of EGFR mutations may achieve more clinical benefits from EGFR-TKI treatment, more sensitive and advanced assays, such as droplet-digital PCR (next-generation quantitative PCR) or next-generation sequencing [46, 47], may be a preferable option to more accurately evaluate EGFR mutation status and confirm "true" wild-type EGFR NSCLC.

\section{ALK rearrangements}

The application of $A L K$ inhibitors has been another representative model of targeted therapy in the treatment of NSCLC. $A L K$ gene rearrangements were first identified in NSCLC in 2007 [48]. Crizotinib, an ALK/ROS1/MET multi-targeted TKI [49], has been approved by the United State Food and Drug Administration (FDA) only 4 years after the first report of $A L K$ rearrangement in NSCLC. $A L K$ rearrangements occur in approximately $3-5 \%$ of NSCLC patients [50-52], more common in patients with adenocarcinoma, younger patients, and never or light smokers as well as generally mutually exclusive with other identified oncogenic drivers. It was reported that the frequency of $A L K$ rearrangement was as high as $33 \%$ in never or light smokers without EGFR mutations [50]. Hence, $A L K$ rearrangements represent another distinct molecular subtype of NSCLC and serve as a novel molecular target in NSCLC, especially for patients who do not harbor activating EGFR mutations.

At present, the role of crizotinib in $A L K$-rearranged NSCLC as second- and first-line settings has been well established in two international, randomized phase III studies [53, 54]. The PROFILE 1007 was a phase III study comparing crizotinib with docetaxel or pemetrexed in $A L K$-rearranged NSCLC as second-line setting [53]. In the PROFILE 1007 study, crizotinib yielded a significant improvement in PFS (7.7 versus 3.0 months; HR, 0.49 ; 95\% CI, $0.37-0.64 ; P<0.001$ ), ORR (65 versus $20 \%$, $P<0.001$ ), and global QoL as compared with chemotherapy [53]. Subsequent PROFILE 1014 study further confirmed the striking efficacy of crizotinib in $A L K$ rearranged NSCLC as first-line treatment [54]. In the
PROFILE 1014 study, 343 patients with $A L K$-rearranged nonsquamous NSCLC were randomly assigned to receive crizotinb (172 patients) or cisplatin plus pemetrexed (171 patients), the most effective chemotherapy regimen in patients with nonsquamous NSCLC. Again, crizotinib demonstrated a superiority over chemotherapy in PFS (10.9 versus 7.0 months; HR, 0.45 ; $95 \%$ CI, $0.35-0.60$; $P<0.001)$ and ORR (74 versus $45 \%, P<0.001)$ (Table 2$)$ [54]. In current clinical practice [55], crizotinib has been a standard care for patients with $A L K$-rearranged NSCLC, and $A L K$ rearrangement should be routinely analyzed in patients with advanced NSCLC, particularly for patients with wild-type EGFR NSCLC.

Ceritinib (LDK378) is a selective, potent, next-generation $A L K$ inhibitor. In a phase I study (ASCEND-1) [56], ceritinib showed promising efficacy in patients with $A L K$-rearranged NSCLC who had been treated with crizotinib previously and who were crizotinib naïve. For patients who were crizotinib naive and treated with at least $400 \mathrm{mg}$ of ceritinib daily, the ORR was $62 \%$. Among patients who had previously received crizotinib, the ORR was $56 \%$ (95\% CI, 45-67\%). The median PFS was 7.0 months in the entire population, 6.9 months in the subgroup of patients who had progressed on crizotinib previously, and 10.4 months in the subgroup of patients who had not received crizotinib previously (Table 2). In contrast to crizotinib, ceritinib also showed activity in patients with brain metastases. The median PFS was 6.9 months in patients with central nervous system (CNS) metastases at baseline, which was similar to that in patients without CNS metastases (7.0 months). In light of the striking results of this phase I study, an expansion cohort trial including $180 A L K$-rearranged NSCLC receiving ceritinib at the recommended dose $(750 \mathrm{mg} /$ day $)$ has been reported at the 2014 American Society of Clinical Oncology (ASCO) Annual Meeting and the results were promising [57].

Alectinib is another potent, second-generation $A L K$ inhibitor. In a phase $1 / 2$, single-arm, open-labelled study (AF-001JP) [58], 93.5\% (43/46) of patients with ALKrearranged NSCLC who had not received crizotinib previously achieved an objective response when receiving alectinib at the recommended dose $(300 \mathrm{mg}$ twice per day). Preclinical studies have demonstrated that alectinib is also active against crizotinib-resistant secondary $A L K$ mutations (including L1196M, C1156Y, and F1174L) [59]. In a more recent phase $1 / 2$ study (AF-002JG) [60], alectinib showed remarkably efficacy in patients with $A L K$-rearranged NSCLC who had progressed on or were intolerant to crizotinib, with an ORR of 55\% (24/44) (Table 2). Among 21 patients with CNS metastases at baseline, 11 (52\%) had an objective response. 
Table 2 Published or presented studies with results in NSCLC patients treated with targeted agents beyond EGFR-TKIs

\begin{tabular}{|c|c|c|c|c|c|c|c|c|}
\hline Target & Agent & Phase & Eligibility & $\begin{array}{l}\text { Number } \\
\text { of patients }\end{array}$ & ORR (\%) & PFS (months) & OS (months) & References \\
\hline \multirow[t]{7}{*}{ ALK } & Crizotinib & III & $\begin{array}{l}\text { Pretreated, } \\
\text { ALK-rearranged }\end{array}$ & 347 & 65 & 7.7 & 20.3 & [53] \\
\hline & Crizotinib & III & $\begin{array}{l}\text { Untreated, } \\
\text { ALK-rearranged }\end{array}$ & 343 & 74 & 10.9 & NR & {$[54]$} \\
\hline & \multirow[t]{3}{*}{ Ceritinib } & \multirow[t]{3}{*}{ । } & \multirow[t]{3}{*}{$\begin{array}{l}\text { Pretreated, } \\
\text { ALK-rearranged }\end{array}$} & \multirow[t]{3}{*}{$\begin{array}{l}114 \text { (at least } \\
400 \mathrm{mg} \text { ) }\end{array}$} & $\begin{array}{l}58 \text { (overall popula- } \\
\text { tion) }\end{array}$ & 7.0 & \multirow[t]{3}{*}{ NR } & \multirow[t]{3}{*}[56]{} \\
\hline & & & & & $\begin{array}{l}56 \text { (crizotinib- } \\
\text { treated) }\end{array}$ & 6.9 & & \\
\hline & & & & & $\begin{array}{l}62 \text { (crizotinib- } \\
\text { naive) }\end{array}$ & 10.4 & & \\
\hline & Alectinib & $|-| \mid$ & $\begin{array}{l}\text { ALK-rearranged } \\
\text { ALK inhibitor-naive }\end{array}$ & 46 & 93.5 & $N R$ & NR & {$[58]$} \\
\hline & Alectinib & $|-| \mid$ & $\begin{array}{l}\text { ALK-rearranged, } \\
\text { crizotinib- } \\
\text { resistant }\end{array}$ & 47 & 55 & $N R$ & $N R$ & {$[60]$} \\
\hline ROS1 & Crizotinib & I & ROS1-rearranged & 50 & 72 & 19.2 & NR & {$[61]$} \\
\hline \multirow[t]{2}{*}{ MET } & \multirow[t]{2}{*}{ Crizotinib } & \multirow[t]{2}{*}{ । } & \multirow[t]{2}{*}{ MET-amplified } & \multirow[t]{2}{*}{13} & $\begin{array}{l}20 \text { (intermediate } \\
\text { amplification) }\end{array}$ & \multirow[t]{2}{*}{ NR } & \multirow[t]{2}{*}{ NR } & \multirow[t]{2}{*}[62]{} \\
\hline & & & & & $\begin{array}{l}50 \text { (high amplifica- } \\
\text { tion) }\end{array}$ & & & \\
\hline BRAF & Dabrafenib & $\|$ & $\begin{array}{l}B R A F^{V 600 E} \text { muta- } \\
\text { tion-positive }\end{array}$ & 17 & 54 & $N R$ & $N R$ & {$[63]$} \\
\hline HER2 & Anti-HER2 agents & $\begin{array}{l}\text { Retrospec- } \\
\text { tive }\end{array}$ & $\begin{array}{l}\text { HER2 mutation- } \\
\text { positive }\end{array}$ & 16 & 50 & 5.1 & $N R$ & {$[64]$} \\
\hline FGFR1 & BGJ398 & । & FGFR1-amplified & 17 & 11.7 & NR & NR & {$[65]$} \\
\hline
\end{tabular}

ALK anaplastic lymphoma kinase, ROS1 c-ros oncogene 1, MET proto-oncogene protein c-met, BRAF v-Raf murine sarcoma viral oncogene homolog B1, HER2 human epidermal growth factor receptor 2, FGFR1 fibroblast growth factor receptor 1, ORR objective response rate, NR not reported or not reached. Other abbreviations as in Table 1.

The question of timing, preferable choice, and sequence of various $A L K$ inhibitors in patients with $A L K$ rearranged NSCLC has not yet been well answered to date. In a more recently retrospective study [66], sequential treatment with crizotinib and ceritinib yielded an impressive survival in $A L K$-rearranged NSCLC, with a PFS of 17.4 months and an OS of 49.4 months. Knowledge regarding the choice of $A L K$ inhibitors will also be expanded from an ongoing, randomized phase 3 trial (NCT02075840), head-to-head comparing alectinib with crizotinib in previously untreated patients with advanced $A L K$-rearranged NSCLC.

\section{ROS1 rearrangements}

ROS1 rearrangements define another distinct molecular subtype of NSCLC and have been identified as a novel oncogenic driver in the targeted therapy of NSCLC [67]. Similar to the clinical features of $A L K$-rearranged NSCLC, ROS1 rearrangement are more likely to be found in younger, never smokers with histologic diagnosis of adenocarcinoma, with an occurrence rate ranging from 1 to $2 \%$ [67-69]. In preclinical studies, crizotinib was active in cell lines harboring ROS1 rearrangement [67, 70]. In a phase I study [61], 50 patients with ROS1-rearranged NSCLC were treated with crizotinib at the standard oral dose of $250 \mathrm{mg}$ twice daily. The ORR was $72 \%$ (95\% CI, 58-84\%), and median PFS was 19.2 months (95\% CI, 14.4 months to not reached) (Table 2). Several phase II trials are underway to evaluate the safety and efficacy of crizotinib in advanced ROS1-rearranged NSCLC in East Asian patient population (NCT01945021) and in European patient population (NCT02183870). An openlabelled, multicenter, phase II trial assessing the efficacy of ceritinib (LDK378) in patients with ROS1-rearranged NSCLC is also ongoing (NCT01964157).

\section{MET amplification}

$M E T$ gene, the only known receptor for hepatocyte growth factor, has been shown to be associated with acquired resistance to EGFR-TKIs in NSCLC patients $[71,72]$. Because the MET signaling pathway could crosstalk with other signaling receptors and $M E T$ amplification could be concomitant with other oncogenic drivers, the role of de novo MET amplification as primary oncogenic driver remains controversial in NSCLC. Recently, dramatic response to crizotinib in patients with de 
novo MET amplification was observed in several case reports [73, 74]. Notably, the reported patients were both absence of other known oncogenic drivers, such as EGFR mutations and $A L K / R O S 1$ rearrangement, suggesting that de novo MET amplification might be a primary oncogenic driver in a subtype of NSCLC. In a more recent phase I study [62], crizotinib showed antitumor activity in patients with $M E T$ amplification, especially in those with high $M E T$ amplification, with an ORR of $50 \%(3 / 6)$ (Table 2). Several small-molecule inhibitor of MET, such as ARQ197 (NCT01244191, NCT01395758, and NCT00777309) and XL184 (NCT00596648), are also being evaluated in advanced NSCLC; however, the enrolled patients are not selected based on $M E T$ expression.

\section{$R E T$ rearrangements}

$R E T$ is a receptor tyrosine kinase that plays an important role in cell proliferation, neuronal navigation, cell migration, and cell differentiation [75]. Recently, RET rearrangements have been demonstrated to be a novel driver oncogene in a subtype of NSCLC [76]. In contrast to thyroid cancer, in which $R E T$ rearrangement is one of the most common molecular alterations and can be found in up to $80 \%$ of tumors [77], RET rearrangements are present only in $1-2 \%$ of patients with NSCLC [76, 78-81]. RET rearrangements tended to occur in patients who were younger than 60 years, never-smokers, with early lymph node metastases, with poorly differentiated tumors, and with a solid-predominant subtype of tumor [76]. Vandetanib, a multi-tyrosine kinase inhibitor that inhibits vascular endothelial growth factor receptor (VEGFR), EGFR, and RET, showed dramatic efficacy in a patient with $R E T$ rearrangement [82]. In contrast to previous studies that evaluated the role of vandetanib in unselected NSCLC, a phase II study is ongoing to investigate the efficacy and safety of vandetanib in patients with advanced NSCLC with RET rearrangements (NCT01823068). Cabozantinib, also a multi-kinase inhibitor and potent inhibitor of $R E T$, demonstrated impressive activity in patients with $R E T$ fusion-positive lung adenocarcinoma [83]. The efficacy of cabozantinib in patients with advanced RET fusion-positive NSCLC is prospectively being evaluated in a phase II study (NCT01639508).

\section{BRAF mutations}

$B R A F$ belongs to the family of $R A F$ kinases, which are intracellular effectors of the mitogen-activated protein kinase (MAPK) signaling cascade [84]. BRAF mutations are generally mutually exclusive of $E G F R$ mutations and proto-oncogene protein p21 (c-Ki-ras) (KRAS) mutations. In a retrospective analysis of 1,046 NSCLC patients in Caucasian population, BRAF mutations were present in 4.9\% (36/739) of lung adenocarcinoma and $0.3 \%$ (1/307) of squamous cell carcinoma (SqCC) [85]. V600E $B R A F$ mutation, a domain subtype of BRAF mutations, was significantly more common in females and was identified in $8.6 \%$ of female patients with adenocarcinoma, which is helpful to identify the enriched patient population for treatment with $B R A F$ inhibitors. Dabrafenib is a potent and selective inhibitor of $B R A F$ kinase activity. In interim analysis of a single-arm, phase II study, 17 pretreated NSCLC patients carrying V600E BARF mutations were treated with dabrafenib [63]. The results were encouraging, with an ORR of $54 \%$ (7 patients with partial response) (Table 2). Dramatic response was also observed in several case reports of NSCLC patients harboring activating V600E $B R A F$ mutations treated with vemurafenib, another inhibitor of $B R A F$ kinase [86-88].

\section{HER2 mutations}

Similar to EGFR, HER2 is also a member of the $E r b B$ family of receptor tyrosine kinases. HER2-targeted agents, such as trastuzumab, pertuzumab, and lapatinib, represent a successful use of targeted therapy for breast cancer with HER2 overexpression or amplification. However, these agents failed to demonstrate significant improvement in survival of NSCLC patients with HER2 overexpression when administered as monotherapy or in combination with chemotherapy [89-91]. Notably, several retrospective studies suggested that NSCLC patients with positive HER2 mutations may benefit from HER2-targeted therapy [64, 92]. In a large retrospective study including 3,800 NSCLC patients, HER2 mutations were present in 65 patients (1.7\%) [64]. In 16 patients receiving subsequent 22 antiHER2 therapies, 11 patients achieved partial response, with an ORR of $50 \%$ and a disease control rate of $82 \%$. The PFS was also encouraging, as long as 5.1 months (Table 2). However, as aforementioned, HER2 mutation is a rare event in lung cancer, with a prevalence of $<2 \%$, a little more frequently in those who are never smokers, adenocarcinoma patients, and females [64, 92, 93].

\section{FGFR1 amplifications}

The FGFR family of tyrosine kinase receptors comprises 4 highly conserved kinases (FGFR1-4) and plays a pivotal role in cancer cell proliferation, migration, angiogenesis, and patient survival [94]. Among the 4 members, FGFR1 amplifications seem to exist exclusively in $\mathrm{SqCC}$, with a presence of about $19 \%$, more common in smokers and patients with lymph node metastasis [95]. Preliminary studies have demonstrated that focal FGFR1 amplification was associated with response to treatment with FGFR inhibitors [96, 97]. In a phase I dose-escalation study, 21 patients with FGFR1-amplified SqCC received 
treatment with a selective pan-FGFR inhibitor (BGJ398) [65]. Among 17 evaluable patients at data cutoff, 2 patients achieved partial response and 3 patients had stable disease (Table 2). A prospective clinical trial assessing the efficacy of ponatinib (a multi-kinase FGFR inhibitor) on advanced SqCC with FGFR kinase alterations is also underway (NCT01761747).

\section{DDR2 mutations}

The $D D R 2$ is a receptor tyrosine kinase, which acts as a collagen receptor and plays a role in cell migration, proliferation, and survival [98]. A preliminary study demonstrated that DDR2 mutations were present in $3.8 \%$ of patients with SqCC and that DDR2 mutations were associated with response to dasatinib, a multi-kinase inhibitor that inhibits $D D R 1$ and DDR2 [99], suggesting $D D R 2$ mutations may be primary oncogenic driver in patients with SqCC. A phase II study is designed to evaluate the efficacy of dasatinib as first- or subsequentline therapy in SqCC patients harboring DDR2 mutations (NCT01514864). However, this trial has been terminated due to the lack of efficacy and slow accrual.

\section{Conclusions and perspectives}

Historically, NSCLC is divided into squamous and nonsqumous types based on histologic features. With a growing number of new oncogenic drivers being identified in squamous and nonsqumous NSCLC, this malignancy has been divided into several distinct subtypes according to the specific molecular alterations. The tremendous advances of EGFR-TKIs represent a success of precise medicine in the treatment of NSCLC. Afterwards, this treatment paradigm of NSCLC has been substantially shifted. In current clinical practice, when a new NSCLC patient is diagnosed, every effort should be made to obtain a tumor sample for genotyping. For patients who have specific oncogenic alterations, matching targeted therapy would be a preferable treatment option. Notably, absence of EGFR mutations does not imply that classical chemotherapy remains the only treatment option. Publications also provide evidence to select appropriate patient population who might benefit from EGFR-TKIs even in patients with wild-type EGFR NSCLC. More importantly, because the majority of driver oncogenes in NSCLC are mutually exclusive of other genetic abnormalities, further molecular analysis of wild-type EGFR NSCLC might identify additional driver oncogenes and provide alternative targeted therapies. In addition, with the help of multiplex genotyping technique [100], it is being able to simultaneously identify multiple genes from one tumor sample. Therefore, we may not be entangled in deciding which oncogenic driver to detect in the near future.
On the other hand, identification of therapeutic targets for SqCC has lagged behind the advances in lung adenocarcinoma. Although plenty of the somatic molecular alterations have been identified in SqCC, targeted therapy for molecularly defined subtypes of SqCC according to specific oncogenic drivers is still underway. Encouragingly, recent advances in the development of immune therapy that blocks the immune checkpoints [101, 102], including programmed death-1 (PD-1) and programmed death-ligand 1/2 (PD-L1/2), highlight the essential role of immune therapy in the treatment of NSCLC in the future, especially for patients with SqCC [103].

\section{Authors' contributions}

FZ and CCZ conceived of and designed the study, conducted the literature review, and drafted the manuscript. Both authors read and approved the final manuscript.

\section{Acknowledgements}

The authors have no support or funding to this research.

Compliance with ethical guidelines

Competing interests

The authors declare that they have no competing interests.

Received: 21 April 2015 Accepted: 25 June 2015

Published online: 18 July 2015

\section{References}

1. Torre LA, Bray F, Siegel RL, Ferlay J, Lortet-Tieulent J, Jemal A. Global cancer statistics, 2012. CA Cancer J Clin. 2015;65(2):87-108.

2. Siegel RL, Miller KD, Jemal A. Cancer statistics, 2015. CA Cancer J Clin. 2015;65(1):5-29

3. Chen W, Zheng R, Zhang S, Zhao P, Li G, Wu L, et al. The incidences and mortalities of major cancers in China, 2009. Chin J Cancer. 2013;32(3):106-12.

4. Schiller JH, Harrington D, Belani CP, Langer C, Sandler A, Krook J, et al. Comparison of four chemotherapy regimens for advanced non-smallcell lung cancer. N Engl J Med. 2002;346(2):92-8.

5. Fossella F, Pereira JR, von Pawel J, Pluzanska A, Gorbounova V, Kaukel E, et al. Randomized, multinational, phase III study of docetaxel plus platinum combinations versus vinorelbine plus cisplatin for advanced non-small-cell lung cancer: the TAX 326 study group. J Clin Oncol. 2003;21(16):3016-24.

6. Wu YL, Zhou C, Hu CP, Feng J, Lu S, Huang Y, et al. Afatinib versus cisplatin plus gemcitabine for first-line treatment of Asian patients with advanced non-small-cell lung cancer harbouring EGFR mutations (LUX-Lung 6): an open-label, randomised phase 3 trial. Lancet Oncol. 2014;15(2):213-22.

7. Sequist LV, Yang JC, Yamamoto N, O'Byrne K, Hirsh V, Mok T, et al. Phase III study of afatinib or cisplatin plus pemetrexed in patients with metastatic lung adenocarcinoma with EGFR mutations. J Clin Oncol. 2013;31(27):3327-34.

8. Rosell R, Carcereny E, Gervais R, Vergnenegre A, Massuti B, Felip E, et al. Erlotinib versus standard chemotherapy as first-line treatment for European patients with advanced EGFR mutation-positive non-small-cell lung cancer (EURTAC): a multicentre, open-label, randomised phase 3 trial. Lancet Oncol. 2012;13(3):239-46.

9. Han JY, Park K, Kim SW, Lee DH, Kim HY, Kim HT, et al. First-SIGNAL: first-line single-agent iressa versus gemcitabine and cisplatin trial in never-smokers with adenocarcinoma of the lung. J Clin Oncol. 2012;30(10):1122-8. 
10. Zhou C, Wu YL, Chen G, Feng J, Liu XQ, Wang C, et al. Erlotinib versus chemotherapy as first-line treatment for patients with advanced EGFR mutation-positive non-small-cell lung cancer (OPTIMAL, CTONG-0802): a multicentre, open-label, randomised, phase 3 study. Lancet Oncol. 2011;12(8):735-42.

11. Mitsudomi T, Morita S, Yatabe Y, Negoro S, Okamoto I, Tsurutani J, et al. Gefitinib versus cisplatin plus docetaxel in patients with non-smallcell lung cancer harbouring mutations of the epidermal growth factor receptor (WJTOG3405): an open label, randomised phase 3 trial. Lancet Oncol. 2010;11(2):121-8.

12. Maemondo M, Inoue A, Kobayashi K, Sugawara S, Oizumi S, Isobe H, et al. Gefitinib or chemotherapy for non-small-cell lung cancer with mutated EGFR. N Engl J Med. 2010;362(25):2380-8.

13. Mok TS, Wu YL, Thongprasert S, Yang CH, Chu DT, Saijo N, et al. Gefitinib or carboplatin-paclitaxel in pulmonary adenocarcinoma. N Engl J Med. 2009;361(10):947-57.

14. Gridelli C, Ciardiello F, Gallo C, Feld R, Butts C, Gebbia V, et al. First-line erlotinib followed by second-line cisplatin-gemcitabine chemotherapy in advanced non-small-cell lung cancer: the TORCH randomized trial. J Clin Oncol. 2012;30(24):3002-11.

15. Shepherd FA, Rodrigues Pereira J, Ciuleanu T, Tan EH, Hirsh V, Thongprasert $\mathrm{S}$, et al. Erlotinib in previously treated non-small-cell lung cancer. $\mathrm{N}$ Engl J Med. 2005;353(2):123-32.

16. Kim ES, Hirsh V, Mok T, Socinski MA, Gervais R, Wu YL, et al. Gefitinib versus docetaxel in previously treated non-small-cell lung cancer (INTEREST): a randomised phase III trial. Lancet. 2008;372(9652):1809-18.

17. Ciuleanu T, Stelmakh L, Cicenas S, Miliauskas S, Grigorescu AC, Hillenbach $C$, et al. Efficacy and safety of erlotinib versus chemotherapy in second-line treatment of patients with advanced, non-small-cell lung cancer with poor prognosis (TITAN): a randomised multicentre, openlabel, phase 3 study. Lancet Oncol. 2012;13(3):300-8.

18. Garassino MC, Martelli O, Broggini M, Farina G, Veronese S, Rulli E, et al. Erlotinib versus docetaxel as second-line treatment of patients with advanced non-small-cell lung cancer and wild-type EGFR tumours (TAILOR): a randomised controlled trial. Lancet Oncol. 2013;14(10):981-8.

19. Kawaguchi T, Ando M, Asami K, Okano Y, Fukuda M, Nakagawa H, et al. Randomized phase III trial of erlotinib versus docetaxel as second- or third-line therapy in patients with advanced non-small-cell lung cancer: Docetaxel and Erlotinib Lung Cancer Trial (DELTA). J Clin Oncol. 2014;32(18):1902-8.

20. Zhou Q, Cheng Y, Yang JJ, Zhao MF, Zhang L, Zhang XC, et al. Pemetrexed versus gefitinib as a second-line treatment in advanced nonsquamous nonsmall-cell lung cancer patients harboring wildtype EGFR (CTONG0806): a multicenter randomized trial. Ann Oncol. 2014;25(12):2385-91.

21. Lee JK, Hahn S, Kim DW, Suh KJ, Keam B, Kim TM, et al. Epidermal growth factor receptor tyrosine kinase inhibitors vs conventional chemotherapy in non-small cell lung cancer harboring wild-type epidermal growth factor receptor: a meta-analysis. JAMA. 2014;311(14):1430-7.

22. Gregorc V, Novello S, Lazzari C, Barni S, Aieta M, Mencoboni M, et al. Predictive value of a proteomic signature in patients with non-smallcell lung cancer treated with second-line erlotinib or chemotherapy (PROSE): a biomarker-stratified, randomised phase 3 trial. Lancet Oncol. 2014;15(7):713-21.

23. Li J, Li X, Ren S, Chen X, Zhang Y, Zhou F, et al. miR-200c overexpression is associated with better efficacy of EGFR-TKls in non-small cell lung cancer patients with EGFR wild-type. Oncotarget. 2014;5(17):7902-16.

24. Ren S, Su C, Wang Z, Li J, Fan L, Li B, et al. Epithelial phenotype as a predictive marker for response to EGFR-TKIs in non-small cell lung cancer patients with wild-type EGFR. Int J Cancer. 2014;135(12):2962-71.

25. Toffalorio F, de Marinis F, Conforti F, Spitaleri G, Catania C, Noberasco $C$, et al. Erlotinib efficacy in NSCLC patients with high polysomy of chromosome 7 and EGFR/KRas wild-type tumors. J Thorac Oncol. 2015;10(2):392-6.

26. Roengvoraphoj M, Tsongalis GJ, Dragnev KH, Rigas JR. Epidermal growth factor receptor tyrosine kinase inhibitors as initial therapy for non-small cell lung cancer: focus on epidermal growth factor receptor mutation testing and mutation-positive patients. Cancer Treatment Rev. 2013;39(8):839-50.
27. Lindeman NI, Cagle PT, Beasley MB, Chitale DA, Dacic S, Giaccone G, et al. Molecular testing guideline for selection of lung cancer patients for EGFR and ALK tyrosine kinase inhibitors: guideline from the College of American Pathologists, International Association for the Study of Lung Cancer, and Association for Molecular Pathology. J Thorac Oncol. 2013;8(7):823-59.

28. Yu J, Kane S, Wu J, Benedettini E, Li D, Reeves C, et al. Mutation-specific antibodies for the detection of EGFR mutations in non-small-cell lung cancer. Clin Cancer Res. 2009;15(9):3023-8.

29. Simonetti S, Molina MA, Queralt C, de Aguirre I, Mayo C, Bertran-Alamillo J, et al. Detection of EGFR mutations with mutation-specific antibodies in stage IV non-small-cell lung cancer. J Transl Med. 2010;8:135.

30. Kato Y, Peled N, Wynes MW, Yoshida K, Pardo M, Mascaux C, et al. Novel epidermal growth factor receptor mutation-specific antibodies for nonsmall cell lung cancer: immunohistochemistry as a possible screening method for epidermal growth factor receptor mutations. J Thorac Oncol. 2010;5(10):1551-8.

31. Kawahara A, Azuma K, Sumi A, Taira T, Nakashima K, Aikawa E, et al. Identification of non-small-cell lung cancer with activating EGFR mutations in malignant effusion and cerebrospinal fluid: rapid and sensitive detection of exon 19 deletion E746-A750 and exon 21 L858R mutation by immunocytochemistry. Lung Cancer. 2011;74(1):35-40.

32. Seo AN, Park TI, Jin Y, Sun PL, Kim H, Chang H, et al. Novel EGFR mutation-specific antibodies for lung adenocarcinoma: highly specific but not sensitive detection of an E746_A750 deletion in exon 19 and an L858R mutation in exon 21 by immunohistochemistry. Lung Cancer. 2014;83(3):316-23.

33. Kawahara A, Yamamoto C, Nakashima K, Azuma K, Hattori S, Kashihara $\mathrm{M}$, et al. Molecular diagnosis of activating EGFR mutations in non-small cell lung cancer using mutation-specific antibodies for immunohistochemical analysis. Clin Cancer Res. 2010;16(12):3163-70.

34. Leighl NB, Rekhtman N, Biermann WA, Huang J, Mino-Kenudson M, Ramalingam SS, et al. Molecular testing for selection of patients with lung cancer for epidermal growth factor receptor and anaplastic lymphoma kinase tyrosine kinase inhibitors: American Society of Clinical Oncology endorsement of the College of American Pathologists/International Association for the study of lung cancer/association for molecular pathology guideline. J Clin Oncol. 2014;32(32):3673-9.

35. Horiike A, Kimura H, Nishio K, Ohyanagi F, Satoh Y, Okumura S, et al. Detection of epidermal growth factor receptor mutation in transbronchial needle aspirates of non-small cell lung cancer. Chest. 2007;131(6):1628-34.

36. Yang Q, Qiu T, Wu W, Zhu C, Liu L, Ying J, et al. Simple and sensitive method for detecting point mutations of epidermal growth factor receptor using cationic conjugated polymers. ACS Appl Mater Interfaces. 2011;3(11):4539-45.

37. Nagai Y, Miyazawa H, Huqun, Tanaka T, Udagawa K, Kato M, et al. Genetic heterogeneity of the epidermal growth factor receptor in non-small cell lung cancer cell lines revealed by a rapid and sensitive detection system, the peptide nucleic acid-locked nucleic acid PCR clamp. Cancer Res. 2005;65(16):7276-82.

38. Cohen V, Agulnik JS, Jarry J, Batist G, Small D, Kreisman H, et al. Evaluation of denaturing high-performance liquid chromatography as a rapid detection method for identification of epidermal growth factor receptor mutations in nonsmall-cell lung cancer. Cancer. 2006;107(12):2858-65.

39. Thomas RK, Baker AC, Debiasi RM, Winckler W, Laframboise T, Lin WM, et al. High-throughput oncogene mutation profiling in human cancer. Nat Genet. 2007;39(3):347-51.

40. Lurkin I, Stoehr R, Hurst CD, van Tilborg AA, Knowles MA, Hartmann A, et al. Two multiplex assays that simultaneously identify 22 possible mutation sites in the KRAS, BRAF, NRAS and PIK3CA genes. PLOS One. 2010;5(1):e8802.

41. Su J, Zhang XC, An SJ, Zhong WZ, Huang Y, Chen SL, et al. Detecting the spectrum of multigene mutations in non-small cell lung cancer by Snapshot assay. Chin J Cancer. 2014;33(7):346-50.

42. Didelot A, Le Corre D, Luscan A, Cazes A, Pallier K, Emile JF, et al. Competitive allele specific TaqMan PCR for KRAS, BRAF and EGFR mutation detection in clinical formalin fixed paraffin embedded samples. Exp Mol Pathol. 2012;92(3):275-80. 
43. Zhao C, Li X, Li J, Zhang Y, Ren S, Chen X, et al. Detecting ALK, ROS1 and RET fusion genes in cell block samples. Transl Oncol. 2014;7(3):363-7.

44. Ellison G, Zhu G, Moulis A, Dearden S, Speake G, McCormack R. EGFR mutation testing in lung cancer: a review of available methods and their use for analysis of tumour tissue and cytology samples. J Clin Pathol. 2013;66(2):79-89.

45. Zhou Q, Zhang XC, Chen ZH, Yin XL, Yang JJ, Xu CR, et al. Relative abundance of EGFR mutations predicts benefit from gefitinib treatment for advanced non-small-cell lung cancer. J Clin Oncol. 2011;29(24):3316-21.

46. Oxnard GR, Paweletz CP, Kuang Y, Mach SL, O'Connell A, Messineo MM, et al. Noninvasive detection of response and resistance in EGFR-mutant lung cancer using quantitative next-generation genotyping of cell-free plasma DNA. Clin Cancer Res. 2014;20(6):1698-705.

47. Diaz LA Jr, Bardelli A. Liquid biopsies: genotyping circulating tumor DNA. J Clin Oncol. 2014;32(6):579-86.

48. Soda M, Choi YL, Enomoto M, Takada S, Yamashita Y, Ishikawa S, et al. Identification of the transforming EML4-ALK fusion gene in non-smallcell lung cancer. Nature. 2007;448(7153):561-6.

49. Christensen JG, Zou HY, Arango ME, Li Q, Lee JH, McDonnell SR, et al. Cytoreductive antitumor activity of PF-2341066, a novel inhibitor of anaplastic lymphoma kinase and c-Met, in experimental models of anaplastic large-cell lymphoma. Mol Cancer Ther. 2007;6(12 Pt 1):3314-22.

50. Shaw AT, Yeap BY, Mino-Kenudson M, Digumarthy SR, Costa DB, Heist RS, et al. Clinical features and outcome of patients with non-small-cell lung cancer who harbor EML4-ALK. J Clin Oncol. 2009;27(26):4247-53.

51. Camidge DR, Doebele RC. Treating ALK-positive lung cancer-early successes and future challenges. Nat Rev Clin Oncol. 2012;9(5):268-77.

52. Blackhall FH, Peters S, Bubendorf L, Dafni U, Kerr KM, Hager H, et al. Prevalence and clinical outcomes for patients with ALK-positive resected stage I to III adenocarcinoma: results from the European Thoracic Oncology Platform Lungscape Project. J Clin Oncol. 2014;32(25):2780-7.

53. Shaw AT, Kim DW, Nakagawa K, Seto T, Crino L, Ahn MJ, et al. Crizotinib versus chemotherapy in advanced ALK-positive lung cancer. N Engl J Med. 2013;368(25):2385-94.

54. Solomon BJ, Mok T, Kim DW, Wu YL, Nakagawa K, Mekhail T, et al. Firstline crizotinib versus chemotherapy in ALK-positive lung cancer. N Engl J Med. 2014;371(23):2167-77.

55. Gridelli C, Peters S, Sgambato A, Casaluce F, Adjei AA, Ciardiello F. ALK inhibitors in the treatment of advanced NSCLC. Cancer Treat Rev. 2014;40(2):300-6.

56. Shaw AT, Kim DW, Mehra R, Tan DS, Felip E, Chow LQ, et al. Ceritinib in ALK-rearranged non-small-cell lung cancer. N Engl J Med. 2014;370(13):1189-97.

57. Kim D, Mehra R, Tan D. Ceritinib in advanced anaplastic lymphoma kinase (ALK)-rearranged (ALK+) non-small cell lung cancer (NSCLC): results of the ASCEND-1 trial. J Clin Oncol. 2014;32:5s(suppl; abstr $8003 \wedge$ ).

58. Seto T, Kiura K, Nishio M, Nakagawa K, Maemondo M, Inoue A, et al. CH5424802 (RO5424802) for patients with ALK-rearranged advanced non-small-cell lung cancer (AF-001.JP study): a single-arm, open-label, phase 1-2 study. Lancet Oncol. 2013;14(7):590-8.

59. Sakamoto H, Tsukaguchi T, Hiroshima S, Kodama T, Kobayashi T, Fukami TA, et al. CH5424802, a selective ALK Inhibitor capable of blocking the resistant gatekeeper mutant. Cancer Cell. 2011;19(5):679-90.

60. Gadgeel SM, Gandhi L, Riely GJ, Chiappori AA, West HL, Azada $M C$, et al. Safety and activity of alectinib against systemic disease and brain metastases in patients with crizotinib-resistant ALKrearranged non-small-cell lung cancer (AF-002JG): results from the dose-finding portion of a phase 1/2 study. Lancet Oncol. 2014;15(10):1119-28.

61. Shaw AT, Ou SH, Bang YJ, Camidge DR, Solomon BJ, Salgia R, et al. Crizotinib in ROS1-rearranged non-small-cell lung cancer. N Engl J Med. 2014;371(21):1963-71.

62. Camidge D, Ou S-H, Shapiro G. Efficacy and safety of crizotinib in patients with advanced c-MET-amplified non-small cell lung cancer (NSCLC). J Clin Oncol. 2014;32:5s(suppl; abstr 8001).

63. Planchard D, Mazieres J, Riely G. Interim results of phase II study BRF 113928 of dabrafenib in BRAF V600E mutation-positive non-small cell lung cancer (NSCLC) patients. J Clin Oncol. 2013;31(suppl; abstr 8029).
64. Mazieres J, Peters S, Lepage B, Cortot AB, Barlesi F, Beau-Faller M, et al. Lung cancer that harbors an HER2 mutation: epidemiologic characteristics and therapeutic perspectives. J Clin Oncol. 2013;31(16):1997-2003.

65. Nogova L, Sequist L, Cassier P. Targeting FGFR1-amplified lung squamous cell carcinoma with the selective pan-FGFR inhibitor BGJ398. J Clin Oncol. 2014;32:5s(suppl; abstr 8034).

66. Gainor JF, Tan DS, De Pas T, Solomon B, Ahmad A, Lazzari C, et al. Progression-free and overall survival in ALK-positive NSCLC patients treated with sequential crizotinib and ceritinib. Clin Cancer Res. 2015;21(12):2745-52.

67. Bergethon K, Shaw AT, Ou SH, Katayama R, Lovly CM, McDonald NT, et al. ROS1 rearrangements define a unique molecular class of lung cancers. J Clin Oncol. 2012;30(8):863-70.

68. Davies KD, Le AT, Theodoro MF, Skokan MC, Aisner DL, Berge EM, et al. Identifying and targeting ROS1 gene fusions in non-small cell lung cancer. Clin Cancer Res. 2012;18(17):4570-9.

69. Cai W, Li X, Su C, Fan L, Zheng L, Fei K, et al. ROS1 fusions in Chinese patients with non-small-cell lung cancer. Ann Oncol. 2013;24(7):1822-7.

70. Yasuda H, de Figueiredo-Pontes LL, Kobayashi S, Costa DB. Preclinical rationale for use of the clinically available multitargeted tyrosine kinase inhibitor crizotinib in ROS1-translocated lung cancer. J Thorac Oncol. 2012;7(7):1086-90.

71. Engelman JA, Zejnullahu K, Mitsudomi T, Song Y, Hyland C, Park JO, et al. MET amplification leads to gefitinib resistance in lung cancer by activating ERBB3 signaling. Science. 2007;316(5827):1039-43.

72. Bean J, Brennan C, Shih JY, Riely G, Viale A, Wang L, et al. MET amplification occurs with or without T790 M mutations in EGFR mutant lung tumors with acquired resistance to gefitinib or erlotinib. Proc Natl Acad Sci USA. 2007;104(52):20932-7.

73. Ou SH, Kwak EL, Siwak-Tapp C, Dy J, Bergethon K, Clark JW, et al. Activity of crizotinib (PF02341066), a dual mesenchymal-epithelial transition (MET) and anaplastic lymphoma kinase (ALK) inhibitor, in a non-small cell lung cancer patient with de novo MET amplification. J Thorac Oncol. 2011;6(5):942-6.

74. Schwab R, Petak I, Kollar M, Pinter F, Varkondi E, Kohanka A, et al. Major partial response to crizotinib, a dual MET/ALK inhibitor, in a squamous cell lung (SCC) carcinoma patient with de novo c-MET amplification in the absence of ALK rearrangement. Lung Cancer. 2014;83(1):109-11.

75. Eng C. RET proto-oncogene in the development of human cancer. J Clin Oncol. 1999;17(1):380-93.

76. Wang R, Hu H, Pan Y, Li Y, Ye T, Li C, et al. RET fusions define a unique molecular and clinicopathologic subtype of non-small-cell lung cancer. J Clin Oncol. 2012;30(35):4352-9.

77. Ciampi R, Nikiforov YE. RET/PTC rearrangements and BRAF mutations in thyroid tumorigenesis. Endocrinology. 2007;148(3):936-41.

78. Takeuchi K, Soda M, Togashi Y, Suzuki R, Sakata S, Hatano S, et al. RET, ROS1 and ALK fusions in lung cancer. Nat Med. 2012;18(3):378-81.

79. Kohno T, Ichikawa H, Totoki Y, Yasuda K, Hiramoto M, Nammo T, et al. KIF5B-RET fusions in lung adenocarcinoma. Nat Med. 2012;18(3):375-7.

80. Lipson D, Capelletti M, Yelensky R, Otto G, Parker A, Jarosz M, et al. Identification of new ALK and RET gene fusions from colorectal and lung cancer biopsies. Nat Med. 2012;18(3):382-4.

81. Cai W, Su C, Li X, Fan L, Zheng L, Fei K, et al. KIF5B-RET fusions in Chinese patients with non-small cell lung cancer. Cancer. 2013;119(8):1486-94.

82. Falchook GS, Ordonez NG, Bastida CC, Stephens PJ, Miller VA, Gaido L, et al. Effect of the RET inhibitor vandetanib in a patient with RET fusionpositive metastatic non-small-cell lung cancer. J Clin Oncol. 2014. doi:10.1200/JCO.2013.50.5016.

83. Drilon A, Wang L, Hasanovic A, Suehara Y, Lipson D, Stephens P, et al. Response to Cabozantinib in patients with RET fusion-positive lung adenocarcinomas. Cancer Discov. 2013;3(6):630-5.

84. Marais R, Light $Y$, Paterson HF, Mason CS, Marshall CJ. Differential regulation of Raf-1, A-Raf, and B-Raf by oncogenic ras and tyrosine kinases. J Biol Chem. 1997;272(7):4378-83.

85. Marchetti A, Felicioni L, Malatesta S, Grazia Sciarrotta M, Guetti L, Chella A, et al. Clinical features and outcome of patients with non-small-cell lung cancer harboring BRAF mutations. J Clin Oncol. 2011;29(26):3574-9.

86. Gautschi O, Pauli C, Strobel K, Hirschmann A, Printzen G, Aebi S, et al. A patient with BRAF V600E lung adenocarcinoma responding to vemurafenib. J Thorac Oncol. 2012;7(10):e23-4. 
87. Peters S, Michielin O, Zimmermann S. Dramatic response induced by vemurafenib in a BRAF V600E-mutated lung adenocarcinoma. J Clin Oncol. 2013;31(20):e341-4

88. Robinson SD, O'Shaughnessy JA, Cowey CL, Konduri K. BRAF V600Emutated lung adenocarcinoma with metastases to the brain responding to treatment with vemurafenib. Lung Cancer. 2014;85(2):326-30.

89. Gatzemeier U, Groth G, Butts C, Van Zandwijk N, Shepherd F, Ardizzoni A, et al. Randomized phase II trial of gemcitabine-cisplatin with or without trastuzumab in HER2-positive non-small-cell lung cancer. Ann Oncol. 2004;15(1):19-27.

90. Zinner RG, Glisson BS, Fossella FV, Pisters KM, Kies MS, Lee PM, et al. Trastuzumab in combination with cisplatin and gemcitabine in patients with Her2-overexpressing, untreated, advanced non-small cell lung cancer: report of a phase II trial and findings regarding optimal identification of patients with Her2-overexpressing disease. Lung Cancer. 2004;44(1):99-110.

91. Clamon G, Herndon J, Kern J, Govindan R, Garst J, Watson D, et al. Lack of trastuzumab activity in nonsmall cell lung carcinoma with overexpression of erb-B2: 39810: a phase II trial of Cancer and Leukemia Group B. Cancer. 2005;103(8):1670-5.

92. De Greve J, Teugels E, Geers C, Decoster L, Galdermans D, De Mey J, et al. Clinical activity of afatinib (BIBW 2992) in patients with lung adenocarcinoma with mutations in the kinase domain of HER2/neu. Lung Cancer. 2012;76(1):123-7.

93. Shigematsu H, Takahashi T, Nomura M, Majmudar K, Suzuki M, Lee $H$, et al. Somatic mutations of the HER2 kinase domain in lung adenocarcinomas. Cancer Res. 2005;65(5):1642-6.

94. Dienstmann R, Rodon J, Prat A, Perez-Garcia J, Adamo B, Felip E, et al. Genomic aberrations in the FGFR pathway: opportunities for targeted therapies in solid tumors. Ann Oncol. 2014;25(3):552-63.

95. Jiang T, Gao G, Fan G, Li M, Zhou C. FGFR1 amplification in lung squamous cell carcinoma: a systematic review with meta-analysis. Lung Cancer. 2015;87(1):1-7.
96. Gozgit JM, Wong MJ, Moran L, Wardwell S, Mohemmad QK, Narasimhan $\mathrm{NI}$, et al. Ponatinib (AP24534), a multitargeted pan-FGFR inhibitor with activity in multiple FGFR-amplified or mutated cancer models. Mol Cancer Ther. 2012;11(3):690-9.

97. Weiss J, Sos ML, Seidel D, Peifer M, Zander T, Heuckmann JM, et al. Frequent and focal FGFR1 amplification associates with therapeutically tractable FGFR1 dependency in squamous cell lung cancer. Sci Transl Med. 2010;2(62):62ra93.

98. Ikeda K, Wang LH, Torres R, Zhao H, Olaso E, Eng FJ, et al. Discoidin domain receptor 2 interacts with $\mathrm{Src}$ and Shc following its activation by type I collagen. J Biol Chem. 2002;277(21):19206-12.

99. Hammerman PS, Sos ML, Ramos AH, Xu C, Dutt A, Zhou W, et al. Mutations in the DDR2 kinase gene identify a novel therapeutic target in squamous cell lung cancer. Cancer Discov. 2011;1(1):78-89.

100. Kris MG, Johnson BE, Berry LD, Kwiatkowski DJ, lafrate AJ, Wistuba II, et al. Using multiplexed assays of oncogenic drivers in lung cancers to select targeted drugs. JAMA. 2014;311(19):1998-2006.

101. Topalian SL, Hodi FS, Brahmer JR, Gettinger SN, Smith DC, McDermott DF, et al. Safety, activity, and immune correlates of anti-PD-1 antibody in cancer. N Engl J Med. 2012;366(26):2443-54.

102. Brahmer JR, Tykodi SS, Chow LQ, Hwu WJ, Topalian SL, Hwu P, et al. Safety and activity of anti-PD-L1 antibody in patients with advanced cancer. N Engl J Med. 2012;366(26):2455-65.

103. Rizvi NA, Mazieres J, Planchard D, Stinchcombe TE, Dy GK, Antonia SJ, et al. Activity and safety of nivolumab, an anti-PD-1 immune checkpoint inhibitor, for patients with advanced, refractory squamous non-smallcell lung cancer (CheckMate 063): a phase 2, single-arm trial. Lancet Oncol. 2015;16(3):257-65.

\section{Submit your next manuscript to BioMed Central and take full advantage of:}

- Convenient online submission

- Thorough peer review

- No space constraints or color figure charges

- Immediate publication on acceptance

- Inclusion in PubMed, CAS, Scopus and Google Scholar

- Research which is freely available for redistribution

Submit your manuscript at

www.biomedcentral.com/submit

C Biomed Central 